Volume 6 No. 2, Desember 2019

P-ISSN: 2406-808X // E-ISSN: 2550-0686

https://journal.iainlangsa.ac.id/index.php/ikhtibar

https://doi.org/10.32505/ikhtibar.v6i2.607

\title{
PENERAPAN METODE MENGHAFAL (FUN TEORY) DAN PROBLEMATIKANYA DALAM PEMBELAJARAN AL-QUR'AN HADITS DI MTS NEGERI 1 LANGSA
}

\author{
IRMA LESTARI \\ Institut Agama Islam Negeri Langsa \\ irma.ksp11@gmail.com
}

\begin{abstract}
The method of memorizing (fun theory) is a memorizing activity that is packaged in an exciting way, because memorization is usually done by being alone, sitting for a long time and boring but not with this method, they memorize as easily as smiling, students while laughing, joking without feeling already done deliberately 'ah in large quantities. This study aims to find out (1) How is the concept of the method of memorizing (fun theory) in learning the Qur'an in the Hadith at MTs Negeri 1 Langsa? (2) What are the problems encountered in learning Al-Qur'an Hadith by using the method of memorizing (fun theory)? (3) What are the steps taken in dealing with these problems? In conducting this research researchers used qualitative research with a descriptive approach. Data collection techniques used are observation, interviews and documentation. Whereas in analyzing data, researchers used the results of interviews and documentation in the field.
\end{abstract}

Keywords: application, method, memorization (fun theory), problems.

\section{Pendahuluan}

Agama Islam mengajarkan sebuah tuntunan kepada manusia untuk menuju kebahagiaan dan kesejahteraan. Adapun segala tuntunan tersebut terdapat dalam AlQur'an dan al Hadits. Al-Qur'an telah melahirkan disiplin ilmu baik itu ilmu nahwu, syaraf, badi', usul, falsafah, politik, ekonomi, sosial, sains, seni, dan lain-lain. Ini berarti bahwa Al-Qur'an selain syarat dengan substansi dan informasi juga memiliki kandungan metodologis dan pedagogis bagi umat manusia.

Banyak hal yang bermanfaat bagi peserta didik apabila mempelajari dan diberi pendidikan tentang Al-Qur'an mengingat isi kandungannya yang penuh dengan petunjuk dan menjadi kewajiban kita umat manusia untuk mempelajari kitab tersebut yaitu AlQur'an. Sebagaimana firman Allah SWT dalam surat al An'am ayat 155 yang berbunyi: 


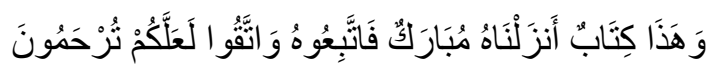

Artinya:"Dan inilah sebuah kitab yang telah kami (Allah) turunkan yang diberkati, maka dari itu turutlah dan bertaqwalah kamu (kepada Allah) supaya kamu diberi rahmat." (Q.S. Al An'am:155)

Ayat di atas menunjukkan bahwa kitab (Al-Qur'an) diberkahi, yang berisi penuh kebaikan untuk kepentingan manusia. Oleh karena itu manusia diperintahkan agar mengikuti dan mempelajari Al-Qur'an supaya diberi rahmat dan petunjuk oleh Allah di dunia maupun di akhirat kelak. ${ }^{2}$

Adapun tujuan pendidikan Al-Qur'an M. Quraish Shihab menyebutkan yaitu membina manusia secara pribadi dan kelompok sehingga mampu menjalankan fungsinya sebagai hamba Allah dan khalifah-Nya guna membangun dunia ini sesuai dengan konsep yang ditetapkan Allah, atau dengan kata lain lebih singkat dan digunakan oleh Al-Qur'an "untuk bertakwa kepada-Nya". 3

Dalam mengkomunikasikan ilmu pengetahuan agar berjalan secara efektif maka perlu menerapkan berbagai metode mengajar sesuai dengan tujuan situasi dan kondisi yang ada guna meningkatkan pembelajaran dengan baik, karena berhasil tidaknya suatu proses belajar mengajar ditentukan oleh metode pembelajaran yang merupakan bagian integral dalam sistem pembelajaran. ${ }^{4}$

Dari uraian di atas dapat disimpulkan bahwa dalam kegiatan proses belajar mengajar salah satu yang disoroti adalah segi metode yang digunakan. Sukses tidaknya suatu proses pembelajaran salah satunya tergantung pada ketepatan metode yang digunakan. Demikian pula dalam pembelajaran Al-Qur'an Hadits juga membutuhkan metode yang tepat. Sebab metodelah yang menentukan isi dan cara mempelajari AlQur'an Hadits tersebut dengan baik. Dengan demikian metode merupakan alat yang sangat penting untuk mencapai tujuan yang telah ditentukan dan direncanakan. Selain itu ketepatan memilih metode dalam penerapannya juga harus diperhatikan. Seperti halnya penggunaan metode menghafal dalam pembelajaran Al-Qur'an Hadits.

Bahwasanya Al-Qur'an Hadits dijadikan bidang pelajaran di sekolah-sekolah Islam di Indonesia. Dengan dikelola oleh Departemen Agama yang membawahi sekolahsekolah negeri maupun swasta dengan kurikulumnya sama-sama mengembangkan ajaran-ajaran Islam. Al-Qur'an Hadits selain dipelajari pada madrasah tingkat pertama yaitu Ibtidaiyah juga dipelajari pada dua madrasah tingkat teratas Tsanawiyah dan Aliyah. $^{5}$

Selain itu ada beberapa hal yang harus diperhatikan kesesuaian metode dengan perkembangan yang terjadi, diantaranya:

a. Kesesuaian antara metode pembelajaran dengan materi ajar, dengan kemampuan dan kebutuhan peserta didik, dengan budaya dan kondisi yang melingkari baik lokal; maupun global, dan tujuan yang akan dicapai.

b. Kesesuaian dan kemampuan metode pembelajaran dengan tumbuh kembangnya budaya di lingkungan sekolah.

\footnotetext{
${ }^{1}$ Departemen Agama RI, Al-Qur'an Dan Terjemahannya, (Semarang: Toha Putra, 2009), hal. 215.

${ }^{2}$ Moenawar Chalil, Kembali Kepada Al Qur'an dan As Sunah, (Jakarta: Bulan Bintang, 2009), hal. 31.

${ }^{3}$ M. Quraish Shihab, Membumikan Al-Qur'an "Fungsi Dan Peran Wahyu Dalam Kehidupan Masyarakat”, (Bandung: Mizan, 2009), hal. 173

${ }^{4}$ Abdul Halim, Metodologi Pembelajaran Agama Islam, (Jakarta: Ciputat Press, 2002), hal. 47.

${ }^{5}$ Howard M. Federspeil, Kajian al Qur'an di Indonesia, terj. Tajul Arifin. (Bandung: Mizan, 2006), hal. 216.
} 
c. Kesesuaian antara metode belajar dengan kemampuan peserta didik dalam menyelesaikan studinya dengan bagus. ${ }^{6}$

Dari uraian di atas menunjukkan bahwa di sekolah-sekolah, perhatian yang amat besar diberikan terhadap Al-Qur'an Hadits mengingat betapa pentingnya yaitu sebagai sumber ajaran dan nilai bagi umat Islam. Dalam mempelajari Al-Qur'an Hadits tersebut tidak hanya memfokuskan pada membaca saja, akan tetapi melibatkan para siswa dalam kegiatan membaca, menelaah dan menghafal Al-Qur'an Hadits, baik secara keseluruhan maupun sebagian surat atau ayat saja.

Sebenarnya untuk menguasai tugas-tugas yang diberikan yaitu menghafal AlQur'an Hadits adalah mudah, akan tetapi mudah pula untuk lupa. MTs Negeri 1 Langsa yang merupakan salah satu Madrasah Tsanawiyah terbaik di Kota Langsa menerapkan beberapa metode dalam pembelajaran Al-Qur' an Hadits seperti membaca, mendengarkan dan menghafal. Ketiga metode ini selalu dipakai oleh guru mata pelajaran. Sebelum menerapkan metode menghafal guru terlebih dahulu meminta siswa membaca materi, ayat atau hadits yang akan di pelajari, lalu guru akan mengulangi membaca ayat atau hadits tersebut agar mereka dapat mendengarkan dan dapat mengoreksi bacaan mereka yang salah, lalu guru meminta mereka menghafal materi tersebut. Terdapat hal berbeda dalam metode menghafal, karena di MTs Negeri 1 Langsa mereka menggunakan metode menghafal (fun teory). ${ }^{7}$

Fun Teory adalah aktivitas menghafal yang dikemas dengan cara yang mengasyikan, karena biasanya aktivitas menghafal dilakukan dengan menyendiri, duduk yang lama dan membosankan tetapi tidak dengan metode ini, mereka menghafal semudah tersenyum, siswa sambil tertawa, bercanda tanpa terasa sudah melakukan muraja'ah dalam jumlah yang banyak.

Sehingga hal ini membuat peneliti tertarik untuk mengadakan penelitian, dalam hal ini lebih memfokuskan pada madrasah tingkat Tsanawiyah, adapun pokok pembahasannya mengenai "Penerapan Metode Menghafal (Fun Teory) dan Problematikanya dalam Pembelajaran Al-Qur'an Hadits di MTs Negeri 1 Langsa". Kajian ini akan menjadi pertimbangan para pengajar dalam kegiatan belajar mengajar di sekolah khususnya bagi pengajar yang menerapkan metode menghafal.

Tujuan penelitian di dalam karya ilmiah merupakan target yang hendak dicapai melalui serangkaian aktivitas penelitian, karena segala yang diusahakan pasti mempunyai tujuan tertentu yang sesuai dengan permasalahannya. Sesuai dengan persepsi tersebut dan berpijak pada rumusan masalah yang telah disebutkan, maka penelitian ini mempunyai tujuan :

a. Untuk mengetahui konsep metode menghafal (fun teory) dalam pembelajaran AlQur'an Hadits di MTs Negeri 1 Langsa

b. Untuk mengetahui Problematika apa saja yang dihadapi dalam pembelajaran AlQur'an Hadits dengan menggunakan metode menghafal (fun teory).

c. Untuk mengetahui langkah apa saja yang dilakukan dalam menghadapi problematika tersebut.

\footnotetext{
${ }^{6}$ Mastuhu, Menata Ulang, Pemikiran System Pendidikan Nasional dalam Abad 21 (The New Mind Set Of Nation Education In The $21^{\text {st }}$ Century), (Yogyakarta: Safrina Insania Press, 2004), hal. 108-109.

${ }^{7}$ Observasi awal di MTs Negeri 1 Langsa pada tanggal 5 Februari 2019.
} 


\section{Metode Penelitian}

Pendekatan yang digunakan dalam penelitian ini adalah pendekatan kualitatif.Menurut Sugiyono, penelitian kualitatif adalah metode penelitian yang digunakan untuk meneliti pada kondisi obyek yang alamiah, (sebagai lawannya adalah eksperimen) dimana peneliti adalah sebagai instrumen kunci, teknik pengumpulan data dilakukan secara triangulasi (gabungan), analisis data bersifat induktif, dan hasil penelitian kualitatif lebih menekankan makna dari pada generalisasi. ${ }^{8}$

Selanjutnya, jika dilihat dari jenis data yang dikumpulkan, maka penelitian ini adalah penelitian deskriptif, yaitu suatu penelitian yang diuraikan dengan kata-kata menurut pendapat informan, apa adanya dan sesuai dengan pertanyaan penelitiannya. Kemudian dianalisis pula dengan kata-kata apa yang melatarbelakangi informan berperilaku (berfikir, berperasaan, dan bertindak) seperti itu tidak seperti lainnya, direduksi, ditriangulasi, disimpulkan (diberi makna oleh peneliti), dan diverifikasi (dikonsultasikan kembali kepada informan dan teman sejawat). Minimal ada tiga hal yang digambarkan dalam penelitian kualitatif yaitu karakteristik pelaku, kegiatan atau kejadian-kejadian yang terjadi selama penelitian, dan keadaan lingkungan atau karakteristik tempat penelitian berlangsung. ${ }^{9}$

Melalui penelitian ini, peneliti berusaha mengungkapkan secara mendalam tentang penerapan metode menghafal (fun teory) dan problematikanya dalam pembelajaran Al-Qur'an Hadits di MTs Negeri 1 Langsa. Data yang dihasilkan dalam penelitian ini berupa kata-kata yang dipaparkan sebagaimana adanya yang terjadi di lapangan, yang dialami, dirasakan, dan dipikirkan oleh partisipan atau sumber data.

Penelitian ini berlokasi di MTs Negeri 1 Langsa terletak di Jln. Jenderal A.Yani Kp. Baroh, Kecamatan Langsa Lama, Kota Langsa, Propinsi Aceh. Waktu penelitian dilaksanakan mulai September sampai dengan September-Oktober 2019. Subjek penelitian atau informan adalah orang yang diminta untuk memberikan keterangan tentang suatu fakta atau pendapat. Sebagaimana dijelaskan oleh Arikunto subjek penelitian adalah subjek yang dituju untuk diteliti oleh peneliti. Jadi, subjek penelitian itu merupakan sumber informasi yang digali untuk mengungkap fakta-fakta di lapangan. ${ }^{10}$ Penentuan subjek penelitian dalam penelitian ini digunakan untuk memperoleh informasi yang dibutuhkan secara jelas dan mendalam. Penentuan subjek penelitian atau informan dalam penelitian ini dilakukan dengan cara purposive sampling. Purposive sampling menurut Djam'an Satori merupakan teknik pengambilan sampel yang ditentukan dengan menyesuaikan pada tujuan penelitian atau pertimbangan tertentu. ${ }^{11}$ Djam'an Satori menambahkan bahwa "purposive sampling sering disebut juga sebagai judgement sampling, secara sederhana diartikan sebagai pemilihan sampel yang disesuaikan dengan tujuan tertentu". ${ }^{2}$

Jadi, pengambilan subjek penelitian atau informan dengan menggunakan purposive sampling dinyatakan cocok dengan masalah penelitian yang peneliti bahas,

9.

${ }^{8}$ Sugiyono, Metode Penelitian Kuantitatif, Kualitatif dan R\&D, (Bandung: Alfabeta, 2015), hal.

${ }^{9}$ Husaini Usman dan Purnomo Setiady Akbar, Metodologi Penelitian Sosial, (Jakarta : Bumi Aksara, 2006), hal. 130.

${ }^{10}$ Suharsimi Arikunto, Prosedur Penelitian : Suatu Pendekatan Praktik, (Jakarta: Rineka Cipta, 2014), hal. 145.

${ }^{11}$ Aan Komariah dan Djam'an Satori, Metode Penelitian Kualitatif, (Bandung: Alfabeta, 2011), hal. 6.

${ }^{12}$ Ibid. 
yaitu penentuan subjek didasarkan atas tujuan peneliti dalam mengungkap masalah yang diangkat dalam penelitian. Subjek penelitian ditentukan berdasarkan orang yang dianggap paling tahu tentang informasi yang dibutuhkan dalam penelitian, sehingga akan memudahkan peneliti dalam menelusuri situasi yang diteliti. Oleh sebab itu maka subjek dalam penelitian ini adalah guru Al-Qur'an Hadits, guru Bahasa Arab, dua murid perempuan dan 2 murid laki-laki yang ada di kelas VII di MTs Negeri 1 Langsa.

Sumber data penelitian kualitatif adalah subjek dari mana data yang di peroleh langsung dari sumbernya, data penelitian digolongkan sebagai data primer dan data sekunder. Untuk memperoleh data yang sesuai dengan permasalahan yang di teliti, maka alat dan teknik pengumpulan data yang digunakan adalahobservasi, wawancara (interview), dan dokumentasi. Sedangkan analisis data adalah proses mencari dan menyusun secara sistematis data yang diperoleh dari hasil wawancara, catatan lapangan, dan dokumentasi, dengan cara mengorganisasikan data ke dalam kategori, menjabarkan ke dalam unit-unit, melakukan sintesa, menyusun kedalam pola, memilih mana yang penting dan yang akan dipelajari, dan membuat kesimpulan sehingga mudah dipahami oleh diri sendiri maupun orang lain. ${ }^{13}$

Model analisis data dalam penelitian ini mengikuti konsep yang diberikan Miles and Huberman. Miles and Hubermen mengungkapkan bahwa aktivitas dalam analisis data kualitatif dilakukan secara interaktif dan berlangsung secara terus-menerus sampai tuntas, sehingga datanya sudah jenuh. ${ }^{14}$ Adapun aktivitas dalam analisis data, yaitu: reduksi data, penyajian data, dan verifikasi atau penyimpulan data.

\section{Hasil dan Pembahasan}

\section{a. Konsep Metode Menghafal (fun teory) dalam Pembelajaran Al-Qur'an Hadits di MTs Negeri 1 Langsa}

Metode dalam rangka sistem pembelajaran memegang peranan yang sangat penting. Keberhasilan implementasi strategi pembelajaran sangat tergantung pada cara guru menggunakan metode pembelajaran karena suatu strategi pembelajaran hanya mungkin dapat diimplementasikan melalui penggunaan metode pembelajaran.

Menurut Bobbi menghafal adalah proses menyimpan data ke memori otak, kemampuan manusia dalam berfikir, berimajiansi dan menyimpan informasi, serta mengeluarkan atau memanggil informasi kembali. ${ }^{15}$ Perlu diketahui otak manusia terbagi dari 3 bagian yaitu otak kanan, otak kiri dan otak tengah. Sementara itu, kemampuan untuk mengingat dan menghafal dikerjakan oleh otak kiri. Menghafal adalah sebuah usaha yang aktif agar dapat memasukkan informasi ke dalam otak. ${ }^{16}$ Sedangkan fun teory yang dimaksud dalam penelitian ini merupakan aktivitas muraja'ah (pengulangan hafalan Al-Qur'an) dibuat semudah tersenyum (banyak tawa dan canda) yang bisa membuat mereka (orang) yang tadinya belum bisa baca Al-Qur'an mampu membaca, menghafal, memahami, dan menulis Al-Qur'an dalam waktu amat singkat. ${ }^{17}$ Jadi, metode menghafal (fun teory) adalah suatu cara untuk menyimpan informasi, serta mengeluarkan atau

\footnotetext{
${ }^{13}$ Sugiyono, Metode Penelitian Kuantitatif..., hal. 244.

${ }^{14}$ Ibid, hal. 246.

${ }^{15}$ Bobbi De Poter, Quantum Teaching, (Bandung: Kaifa, 2007), hal. 168.

${ }^{16}$ Chatrine Syarif, Menjadi Pintar dengan Otak Tengah, (Yogyakarta: Buku Kuta, 2010), hal. 111112.

17 Bobby Herwibowo, Teknik Quantum Rasulullah (Fun dan Cepat Menghafal Al-Qur'an), (Jakarta: Noura Books, 2014), hal. 125.
} 
memanggil informasi kembali dengan aktivitas muraja'ah (pengulangan hafalan AlQur'an) dibuat semudah tersenyum (banyak tawa dan canda). Adapun metode menghafal (fun teory) yang dipraktekkan guru yaitu Ibu Hindun, S.Ag adalah sebagai berikut:

"Awal mula memperkenalkan metode menghafal (fun teory) mengalami kesulitan, karena metode ini menggunakan gerakan tangan disaat mulai menghafap ayat-ayat Al-Qur'an dan respon dari beberapa murid ada yang tertawa dan heran. Jadi, Ibu mengajarkan metode ini kepada murid dengan cara mengulang ayat yang tidak terlalu panjang, karena untuk awal murid harus paham antara gerakan tangan dengan ayat yang ingin dihafal. Tetapi sekarang setelah lama menerapkan metode ini, hasilnya Alhamulillah memuaskan, karena banyak dari murid-murid yang awalnya bermalasmalasan untuk menghafal, sekarang berantusias menghafal dengan metode ini". ${ }^{18}$

Hal yang hampir sama pun terjadi oleh seorang guru yang mengajarkan metode menghafal (fun teory) kepada murid-murid, guru tersebut adalah Bapak Khalis Hasan, S.Pd.I, beliau mengatakan:

"Waktu awal mempraktekkan gerakan tangan dengan bacaan ayat-ayat Al-Qur'an, respon daripada murid ada yang senang karena pernah melihat di televisi ataupun youtube serta sangat antusias ingin mempelajarinya dan ada yang merasa biasa saja, mungkin bagi murid metode ini belum pernah diliat sebelumnya. Sekarang hasil dari metode ini adalah murid-murid dapat dengna mudah, cepat, dan senang dalam menghafal ayat-ayat Al-Qur'an". 19

Jadi, menghafal sambil melakukan suatu gerakan sangat mampu mengaktifkan memori. Otak kita memiliki satu pusat kecerdasan yang disebut bodily-kinesthetycintellegence kecerdasan gerak. Dengan melakukan gerakan tertentu akan memicu pusat kecerdasan ini aktif. ${ }^{20}$

Untuk mengukur keefektifan dari metode menghafal (fun teory), guru biasanya melakukan penilaian apakah ada peningkatan dari murid yang menghafal menggunakan metode ini, seperti Hindun, S.Ag mengatakan:

"Ibu menggunakan sistem penilaian setiap minggu, jadi setiap murid yang telah dapat menambah hafalannya dengan menggunakan metode menghafal (fun teory), maka murid dipersilahkan maju ke depan kelas untuk mempraktekkannya, setelah itu Ibu mencatatnya di buku penilaian yang telah dibuat sebelumnya. Dari buku inilah Ibu mengetahui murid mana saja yang telah banyak menghafal ayat-ayat Al-Qur'an'. ${ }^{21}$

Sedangkan penilaian yang dilakukan oleh guru Bapak Khalis Hasan, S.Pd.I, tidak jauh berbeda dengan Ibu Hindun, S.Ag. Bapak Khalis Hasan, S.Pd.I, mengatakan:

"Penilaian yang Bapak terapkan ialah murid yang telah lancar menghafal dengan menggunakan metode menghafal (fun teory) dipersilahkan ke depan untuk mempraktekkannya, tidak ada unsur paksaan kepada murid, sebab tujuan dari menghafal ini agar para murid lebih termotivasi lagi dengan kemudahan menggunakan metode ini. Namun, murid yang telah berhasil menambah hafalannya

${ }^{18}$ Hasil wawancara dengan Ibu Hindun, S.Ag, guru Al-Qur'an Hadits kelas VII dan VIII di MTsN 1 Langsa pada tanggal 28 September 2019.

${ }^{19}$ Hasil wawancara dengan Bapak Khalis Hasan, S.Pd.I, guru Bahasa Arab kelas VII dan VIII di MTsN 1 Langsa pada tanggal 01 Oktober 2019.

${ }^{20}$ Masagus A. Fauzan dan Farid Wajdi, Quantum Tahfiz (Siapa Bilang Menghafal Al-Qur'an Susah?), (Bandung: YKM Press, 2010), hal. 201.

${ }^{21}$ Hasil wawancara dengan Ibu Hindun, S.Ag, guru Al-Qur'an Hadits kelas VII dan VIII di MTsN 1 Langsa pada tanggal 28 September 2019. 
harus Bapak catat di buku penilaian, agar kelak dapat mengetahui murid mana saja yang telah banyak hafalannya". ${ }^{22}$

Dari hasil wawancara di atas mengenai konsep metode menghafal (fun teory) dalam pembelajaran Al-Qur'an Hadits di MTs Negeri 1 Langsa, maka penulis menyimpulkan bahwa menghafal ayat Al-Qur'an dengan menggunakan gerakan tangan mampu mewakili makna dari ayat yang dibaca dan penilaian yang dilakukan oleh guru berfungsi untuk mengetahui murid-murid mana saja yang telah banyak memiliki hafalan Al-Qur'an.

Adapun pendapat dari beberapa murid berkaitan dengan penerapan metode menghafal (fun teory) di MTsN 1 Langsa, seperti pendapat dari Khaliza Junia Putri dan Intan Nursalma murid kelas VII, mereka menuturkan bahwa:

"Metode menghafal (fun teory) yang diajarkan guru sangat menyenangkan, karena cara menghafalnya berbeda daripada biasanya yaitu ada tambahan gerakan tangan. Kata guru, fungsi gerakan tangan ini untuk mengetahui makna dari ayat tersebut sehingga selain bisa menghafal, maka kami dapat mengerti makna dari surat AlQur'an tersebut. Untuk awal-awal mempraktekkan metode ini sangat susah, tetapi dengan berlatih terus menerus maka akan sangat mudah mempratekkannya. Alhamdulillah sekarang kami dapat menambah hafalan-hafalan setiap minggunya yang disetor kepada guru". 23

Pendapat yang sama disampaikan oleh murid yang bernama Wira Jailani dan Afdal Anil Syahputra, mereka menuturkan bahwa:

"Untuk awal diberitahu tentang metode menghafal (fun teory) oleh guru, kami merasa heran karena belum pernah melihat metode ini. Namun setelah dijelaskan sambil dipraktekkan, baru kami mengetahui maksud dan tujuan dari metode ini. Sekarang kami telah mengetahui cara menggunakan metode ini, yaitu gerakan tangan disesuaikan dengan hafalan ayat Al-Qur'an, meskipun ada kesulitan mensesuaikan hafalan dengan gerakan tangan, tetapi kami yakin metode ini sangat bagus untuk menghafal ayat Al-Qur'an". ${ }^{24}$

Dari hasil wawancara di atas dengan murid, penulis menyimpulkan bahwa metode menghafal (fun teory) ini sangat membantu untuk menghafal Al-Qur'an, sebab dengan metode ini dapat membuat murid lebih giat lagi untuk menghafal Al-Qur'an dengan menggunakan gerakan tangan yang berfungsi untuk mengetahui makna dari ayat AlQur'an.

\section{b. Problematika yang dihadapi dalam pembelajaran Al-Qur'an Hadits dengan menggunakan metode menghafal (fun teory)}

Setiap perjalanan pastilah akan menemui rintangan, begitu pula dengan penghafalan Al-Qur'an. Dalam prosesnya seringkali berhadapan dengan problem yang bermacam-macam sebab menghafal Al-Qur'an diperlukan kerja keras dan kesabaran yang terus menerus. Ini sesungguhnya telah menjadi karakteristik Al-Qur'an itu sendiri. Kalau anda perhatikan dengan baik, maka isinya mengajak anda untuk menjadi orang yang aktif dalam hidup di dunia.

\footnotetext{
${ }^{22}$ Hasil wawancara dengan Bapak Khalis Hasan, S.Pd.I, guru Bahasa Arab kelas VII dan VIII di MTsN 1 Langsa pada tanggal 01 Oktober 2019.

${ }^{23}$ Hasil wawancara dengan Khaliza Junia Putri dan Intan Nursalma, murid kelas VII di MTsN 1 Langsa pada tanggal 01 Oktober 2019.

${ }^{24}$ Hasil wawancara dengan Wira Jailani dan Afdal Anil Syahputra, murid kelas VII di MTsN 1 Langsa pada tanggal 01 Oktober 2019.
} 
Secerdas apapun seseorang, pasti tidak akan luput dari masalah lupa. Hal inilah yang menuntut adanya pengulangan-pengulangan dalam rangka selalu memelihara hafalan Al-Qur'an, agar tidak hilang karena lupa. Tetapi faktor utama keberhasilan dalam berbuat sesuatu adalah semangat. Begitu juga dalam menghafal Al-Qur'an. Tanpa dilandasi semangat dan keinginan yang kuat, maka mustahil akan berhasil dalam menghafal Al-Qur'an. Adapun problematika yang dihadapi guru dalam mengajarkan metode menghafal (fun teory) di MTsN 1 Langsa ada dari faktor internal maupun eksternal, seperti ungkapan dari Ibu Hindun, S.Ag. sebagai berikut:

"Faktor internal yang sering terjadi adalah lupa, murid kelas VII masih memiliki pemikiran yang masih kanak-kanak yang dalam ingatannya hanya ingin bermainmain saja dan faktor internal lainnya adalah keinginan yang lemah untuk dapat menghafal ayat-ayat Al-Qur'an, sebab kesadaran dari murid terbilang masih minim, jadi murid masih enggan untuk menghafal Al-Qur'an lebih banyak lagi, hanya sebatas ayat-ayat pendek saja. Sedangkan faktor eksternal adalah ayat-ayat yang mirip dalam Al-Qur'an dan pengulangan yang sedikit, sehingga murid mengalami kesulitan karena terdapat ayat-ayat yang miripatau serupa untuk mensesuaikan hafalan dengan gerakan tangannya serta pengulangan sedikit akan menyebabkan hafalan yang telah diperoleh menjadi hilang atau terlupakan lagi, sebab untuk mendapatkan hasil hafalan yang maksimal membutuhkan pengulangan berkali-kali". ${ }^{25}$

Sedangkan menurut Bapak Khalis Hasan, S.Pd.I, tentang faktor internal dan eksternal dalam mengajarkan metode menghafal (fun teory) di MTsN 1 Langsa, beliau mengatakan:

"Untuk faktor internal yang Bapak alami dalam mengajarkan metode ini yaitu lupa, karena banyak murid tidak bisa menghafal disebabkan sering lupa atau tidak mengingat sambungan ayatnya. Sedangkan untuk faktor eksternalnya ada dua, pertama tidak mampu membaca dengan baik, sebab dalam menghafal diharuskan lancar dalam membaca Al-Qur'an, baik makraj maupun tajwidnya. Kedua, tidak mampu mengatur waktu, jika tidak bisa mengatur waktu dalam mengulang hafalan, maka akan cepat hilang hafalan yang telah dihafal sebelumnya". ${ }^{26}$

Dari hasil wawancara di atas mengenai problematika yang dihadapi dalam pembelajaran Al-Qur'an Hadits dengan menggunakan metode menghafal (fun teory), maka penulis menyimpulkan bahwa ada dua faktor problemnya, pertama faktor internal seperti lupa dan keinginan yang lemah atau kurang semangatnya anak dalam menghafal Al-Qur'an. Kedua faktor eksternal seperti ayat-ayat yang mirip dalam Al-Qur'an, pengulangan yang sedikit, tidak mampu membaca dengan baik dan tidak mampu mengatur waktu.

Adapun pendapat dari beberapa murid berkaitan dengan problematika yang dihadapi dalam pembelajaran Al-Qur'an Hadits dengan menggunakan metode menghafal (fun teory), seperti pendapat dari Khaliza Junia Putri dan Intan Nursalma murid kelas VII, mereka menuturkan bahwa:

"Selain faktor dari sendiri yaitu lupa dan ada rasa malas untuk memulai mengahafal Al-Qur'an, gerakan tangan yang hampir sama disetiap menghafal ayat demi ayat merupakan permasalahan bagi kami, belum lagi ditambah dengan ayat yang panjang

\footnotetext{
${ }^{25}$ Hasil wawancara dengan Ibu Hindun, S.Ag, guru Al-Qur'an Hadits kelas VII dan VIII di MTsN 1 Langsa pada tanggal 28 September 2019.

${ }^{26}$ Hasil wawancara dengan Bapak Khalis Hasan, S.Pd.I, guru Bahasa Arab kelas VII dan VIII di MTsN 1 Langsa pada tanggal 01 Oktober 2019.
} 
yang membuat kami berusaha terus untuk berlatih agar gerakan tangan telah sesuai dengan hafalan ayat yang ingin dibaca". ${ }^{27}$

Pendapat yang sama disampaikan oleh murid yang bernama Wira Jailani dan Afdal Anil Syahputra, mereka menuturkan bahwa:

"Kadang rasa ingin bermain lebih banyak daripada menghafal dan ini merupakan faktor internal yang kami alami selain kesulitan untuk menghafal Al-Qur'an dengan gerakan tangan. Tapi dengan motivasi yang selalu diberikan oleh guru, kami makin berusaha berlatih dengan mengulang-ulang hafalan ayat demi ayat menggunakan gerakan tangan". ${ }^{28}$

Dari hasil wawancara di atas dengan murid, penulis menyimpulkan bahwa problem yang dihadapi dari murid itu berasal dari diri mereka sendiri, seperti sifat pelupa, rasa malas, dan selalu ingin bermain. Namun dengan adanya motivasi dari guru dan metode menghafal (fun teory) ini dapat membuat murid lebih giat lagi untuk mengulangulang hafalan Al-Qur'an mereka.

\section{c. Langkah yang dilakukan Menghadapi Problematika dalam Pembelajaran Al- Qur'an Hadits dengan Menggunakan Metode Menghafal (fun teory)}

Di dalam menghafal Al-Qur'an perlu diperhatikan bagi seorang penghafal AlQur'an. Untuk menjadi seorang Hafidz Qur'an yang berhasil, harus memperhatikan faktor-faktor yang mempengaruhi dalam proses menghafal Al-Qur'an. Menurut Raghib As-Sirjani menjelaskan bahwa usia emas dalam menghafal adalah usia 5 tahun sampai kira-kira usia 23 tahun. Pada usia ini, kekuatan hafalan manusia sangat bagus. Bahkan usia tersebut merupakan tahun-tahun emas yang sangat berharga untuk menghafal. ${ }^{29}$ Kemudian hal-hal yang dapat menguat hafalan menurut Az-Zarnuji, ialah tekun atau rajin belajar, aktif mengurangi makan, salat malam, dan membaca Al-Qur'an. Adapun yang dapat merusak hafalan adalah banyak berbuat maksiat, banyak dosa, banyak susah, prihatin memikirkan urusan harta, dan terlalu banyak bekerja. ${ }^{30}$

Langkah-langkah yang dilakukan guru untuk menghadapi problematika dalam menggunakan metode menghafal (fun teory) pada pembelajara Al-Qur'an Hadits di MTsN 1 Langsa dapat penulis bagi menjadi dua langkah, yaitu:

1. Memperbaiki faktor internal siswa

Menurut Ibu Hindun, S.Ag, cara memperbaiki faktor internal dalam mengajar menggunakan metode menghafal (fun teory) pada pembelajara Al-Qur'an Hadits di MTsN 1 Langsa, adalah:

"Faktor internalnya adalah lupa dan keinginan yang lemah untuk menghafal Al-

Qur'an. Jadi cara mengatasi kedua faktor internal ini, biasanya Ibu memberi motivasi seperti kalimat-kalimat bijak yang dapat membangkitkan rasa ingin menghafalnya lebih kuat lagi dan tidak cepat lupa". 31

\footnotetext{
${ }^{27}$ Hasil wawancara dengan Khaliza Junia Putri dan Intan Nursalma, murid kelas VII di MTsN 1 Langsa pada tanggal 01 Oktober 2019.

${ }^{28}$ Hasil wawancara dengan Wira Jailani dan Afdal Anil Syahputra, murid kelas VII di MTsN 1 Langsa pada tanggal 01 Oktober 2019.

${ }^{29}$ Raghib As-Sirjani dan Abdurahman Abdul Khaliq, Cara Cepat Hafal Al-Qur'an, Terj. Sarwedi Hasibuan dan Arif Mahmudi, (Solo: Aqwam Media Profetika, 2012), hal. 123.

${ }^{30}$ Az-Zarnuji, Ta'lim Muta'alim, Terj. Abdul Kadir Al Jufri, (Surabaya: Mutiara Ilmu, 2009), hal. 97-99

${ }^{31}$ Hasil wawancara dengan Ibu Hindun, S.Ag, guru Al-Qur'an Hadits kelas VII dan VIII di MTsN 1 Langsa pada tanggal 28 September 2019.
} 
Menurut Imam Syafi'i dalam Al-Ghautsani, ada enam perkara yang harus dimiliki oleh penghafal Al-Qur'an yaitu:

a. Kecerdasan yaitu kecerdasan yang merupakan anugerah dan pemberian Allah SWT dan kecerdasan yang diperoleh dengan usaha, dan keduanya pada hakekatnya berasal dari Allah SWT.

b. Perhatian penuh, hendaklah memperhatikan guru yang sedang menjelaskan betapa berharganya hal-hal yang berfaedah ini, ia juga yang menyingkapkan, ialah yang meluruskan jalan ketika berbelok dan ia pula yang memudahkan melalui rintanganrintangan yang menghalangi.

c. Bersungguh-sungguh, berarti mengerahkan daya dan upaya demi meraih sesuatu. Sedangkan yang dimaksud disini adalah keinginan yang tinggi, kontinyu setiap hari dan selalu mengingat-ingat dan me-muraja'ah hafalan.

d. Bekal yang memadai, yaitu mempelajari Al-Qur'an haruslah mencari dengan sungguh-sungguh bekal yang halal dan makanan yang baik ketika mempelajarinya.

e. Bersahabat dengan guru, berarti dalam upaya meraih ilmu dan mempelajari Al-Qur'an tidak mungkin dapat tercapai tanpa guru yang mumpuni. Ada sebuah ungkapan: "barang siapa yang gurunya hanyalah buku yang dibacanya, maka kesalahannya lebih banyak daripada kebenarannya".

f. Waktu yang lama, berarti seseorang tidak akan memperoleh ilmu kecuali dengan waktu luang, harta, menghafal dan bersikap wara' (apik). ${ }^{32}$

Sedangkan menurut Bapak Khalis Hasan, S.Pd.I, cara untuk mengatasi faktor internal dalam metode ini, adalah:

"Bapak biasanya selalu memberi motivasi kepada murid-murid yang menghafalnya belum sempurna, seperti sering lupa pada ayat sambungannya. Karena semua membutuhkan proses, apalagi di usia mereka yang masih muda ini masih panjang perjalanannya. Jadi, di akhir pelajaran Bapak memberikan kalimat yang dapat memotivasi para murid untuk lebih giat lagi menghafal Al-Qur'an". 33

2. Memperbaiki faktor eksternal siswa

Faktor eksternal merupakan faktor yang ada atau di dapat dari luar lingkungan sekolah. Berdasarkan hasil wawancara penulis dengan Ibu Hindun, S.Ag, cara memperbaiki atau mengatasi faktor eksternal ini adalah:

"Faktor eksternalnya ada dua, pertama, murid mengatakan bahwa ayat-ayat yang mirip dalam Al-Qur'an sehingga susah menghafalkannya, dan yang kedua, pengulangan yang sedikit dikarenakan kebanyakan main bersama teman-teman, baik di lingkungan sekolah maupun di luar sekolah. Jadi, untuk mengatasi ini biasanya Ibu bekerjasama dengan para orangtua agar dapat membimbingnya lagi sewaktu berada di rumah, karena dengan perhatian dan bimbingan orangtua dapat menjaga dan memelihara hafalan Al-Qur'an dari si murid,", 34

Sedangkan menurut Bapak Khalis Hasan, S.Pd.I, cara untuk mengatasi faktor eksternal dalam metode ini adalah dengan adanya kerjasama antara guru dan orangtua, berikut pernyataan beliau:

\footnotetext{
${ }^{32}$ Yahya Bin 'Abdurrazzaq Al-Ghautsani, Cara Mudah dan Cepat Menghafal Al-Qur'an, Terj. Zulfan. (Jakarta: Pustaka Imam As-Syafi'i, 2004), hal. 41-42.

${ }^{33}$ Hasil wawancara dengan Bapak Khalis Hasan, S.Pd.I, guru Bahasa Arab kelas VII dan VIII di MTsN 1 Langsa pada tanggal 01 Oktober 2019.

${ }^{34}$ Hasil wawancara dengan Ibu Hindun, S.Ag, guru Al-Qur'an Hadits kelas VII dan VIII di MTsN 1 Langsa pada tanggal 28 September 2019.
} 
"Dengan bentuk kerjasama antara guru dengan para orangtua murid, maka akan dapat mengatasi problem eksternal seperti tidak mampu membaca dengan baik dan tidak mampu mengatur waktu. Jadi, dengan kerjasama ini diharapkan para orangtua murid dapat mengetahui letak kekurangan dan kelebihan dari anaknya yang ingin menghafal Al-Qur'an sampai 30 juz". 35

Dari hasil wawancara di atas Langkah yang dilakukan menghadapi problematika dalam pembelajaran Al-Qur'an Hadits dengan menggunakan metode menghafal (fun teory), maka penulis menyimpulkan bahwa dalam memperbaiki/ mengatasi faktor internal, guru memberikan motivasinya dengan kalimat-kalimat yang membangun kepada para murid agar dapat meningkatkan lagi hafalan Al-Qur'annya. Sedangkan memperbaiki/ mengatasi faktor eksternal, guru memilih bekerjasama dengan para orangtua murid, karena dengan bekerjasama ini para orang tua akan mengetahui sampai mana anaknya sudah bisa menghafal Al-Qur'an dan dimana saja letak kekurangan dan kelebihannya agar di rumah orangtua akan memberi perhatian dan bimbingan lagi.

\section{Kesimpulan}

Dari hasil penelitian ini, maka peneliti dapat menyimpulkan beberapa hal yaitu:

1. Menghafal ayat Al-Qur'an dengan menggunakan gerakan tangan merupakan konsep dari metode menghafal (fun teory), karena gerakan tangan mampu mewakili makna dari ayat yang dibaca dan penilaian yang dilakukan setiap minggunya oleh guru berfungsi untuk mengetahui murid-murid mana saja yang telah banyak memiliki hafalan Al-Qur'an.

2. Terdapat dua faktor problematika menggunakan metode menghafal (fun teory), pertama faktor internal seperti lupa dan keinginan yang lemah atau kurang semangatnya anak dalam menghafal Al-Qur'an. Kedua faktor eksternal seperti ayatayat yang mirip dalam Al-Qur'an, pengulangan yang sedikit, tidak mampu membaca dengan baik dan tidak mampu mengatur waktu.

3. Langkah yang dilakukan guru dalam menghadapi problematika menggunakan metode menghafal (fun teory) yaitu memperbaiki/ mengatasi faktor internal, seperti guru memberikan motivasinya dengan kalimat-kalimat yang membangun kepada para murid agar dapat meningkatkan lagi hafalan Al-Qur'annya. Sedangkan memperbaiki/ mengatasi faktor eksternal, seperti guru memilih bekerjasama dengan para orangtua murid, karena dengan bekerjasama ini para orang tua akan mengetahui sampai mana anaknya sudah bisa menghafal Al-Qur'an dan dimana saja letak kekurangan dan kelebihannya agar di rumah orangtua akan memberi perhatian dan bimbingan lagi.

\section{Daftar Pustaka}

Komariah, Aan, dan Satori, Djam'an, Metode Penelitian Kualitatif, Bandung: Alfabeta, 2011.

Halim, Abdul, Metodologi Pembelajaran Agama Islam, Jakarta: Ciputat Press, 2002.

Az-Zarnuji, Ta'lim Muta'alim, Terj. Abdul Kadir Al Jufri, Surabaya: Mutiara Ilmu, 2009.

\footnotetext{
${ }^{35}$ Hasil wawancara dengan Bapak Khalis Hasan, S.Pd.I, guru Bahasa Arab kelas VII dan VIII di MTsN 1 Langsa pada tanggal 01 Oktober 2019.
} 
De Poter, Bobbi, Quantum Teaching, Bandung: Kaifa, 2007.

Herwibowo, Bobby, Teknik Quantum Rasulullah (Fun dan Cepat Menghafal Al-Qur'an), Jakarta: Noura Books, 2014.

Syarif, Chatrine, Menjadi Pintar dengan Otak Tengah, Yogyakarta: Buku Kuta, 2010.

Departemen Agama RI, Al-Qur'an Dan Terjemahannya, Semarang: Toha Putra, 2009.

Federspeil, Howard M., Kajian al Qur'an di Indonesia, terj. Tajul Arifin. Bandung: Mizan, 2006.

Usman, Husaini, dan Setiady Akbar, Purnomo,Metodologi Penelitian Sosial, Jakarta : Bumi Aksara, 2006.

Shihab, M. Quraish, Membumikan Al-Qur'an "Fungsi Dan Peran Wahyu Dalam Kehidupan Masyarakat”,Bandung: Mizan, 2009.

Fauzan, Masagus A., dan Wajdi, Farid, Quantum Tahfiz (Siapa Bilang Menghafal AlQur'an Susah?), Bandung: YKM Press, 2010.

Mastuhu, Menata Ulang, Pemikiran System Pendidikan Nasional dalam Abad 21 (The New Mind Set Of Nation Education In The $21^{\text {st }}$ Century), Yogyakarta: Safrina Insania Press, 2004.

Chalil, Moenawar, Kembali Kepada Al Qur'an dan As Sunah, Jakarta: Bulan Bintang, 2009.

As-Sirjani, Raghib, dan Khaliq, Abdurahman Abdul, Cara Cepat Hafal Al-Qur'an, Terj. Sarwedi Hasibuan dan Arif Mahmudi, Solo: Aqwam Media Profetika, 2012.

Sugiyono, Metode Penelitian Kuantitatif, Kualitatif dan R\&D, Bandung: Alfabeta, 2015.

Arikunto, Suharsimi, Prosedur Penelitian : Suatu Pendekatan Praktik, Jakarta: Rineka Cipta, 2014.

Al-Ghautsani, Yahya Bin 'Abdurrazzaq, Cara Mudah dan Cepat Menghafal Al-Qur'an, Terj. Zulfan. Jakarta: Pustaka Imam As-Syafi’i, 2004. 